Article

\title{
Effects of Random Mutagenesis and In Vivo Selection on the Specificity and Stability of a Thermozyme
}

\author{
Giuseppe Perugino ${ }^{1,+} \oplus^{\oplus}$, Andrea Strazzulli ${ }^{2,3, \dagger}$, Marialuisa Mazzone ${ }^{1}$, Mosè Rossi ${ }^{1}$ and \\ Marco Moracci $1,2,3, *$ (D) \\ 1 Institute of Biosciences and BioResources - National Research Council of Italy, Via P. Castellino 111, \\ 80131 Naples, Italy; giuseppe.perugino@ibbr.cnr.it (G.P.); marialuisam76@yahoo.it (M.M.); \\ mose.rossi@ibbr.cnr.it (M.R.) \\ 2 Department of Biology, University of Naples "Federico II", Complesso Universitario di Monte S. Angelo, \\ Via Cintia 21, 80126 Napoli, Italy; andrea.strazzulli@unina.it \\ 3 Task Force on Microbiome Studies, University of Naples Federico II, 80126 Naples, Italy \\ * Correspondence: marco.moracci@unina.it; Tel.: +39-081-679046; Fax: +39-081-679233 \\ + These authors contributed equally to the paper as First Authors.
}

Received: 18 April 2019; Accepted: 9 May 2019; Published: 11 May 2019

\begin{abstract}
Factors that give enzymes stability, activity, and substrate recognition result from the combination of few weak molecular interactions, which can be difficult to study through rational protein engineering approaches. We used irrational random mutagenesis and in vivo selection to test if a $\beta$-glycosidase from the thermoacidophile Saccharolobus solfataricus (Ss $\beta$-gly) could complement an Escherichia coli strain unable to grow on lactose. The triple mutant of Ss $\beta$-gly (S26L, P171L, and A235V) was more active than the wild type at $85^{\circ} \mathrm{C}$, inactivated at this temperature almost 300-fold quicker, and showed a 2-fold higher $\mathrm{k}_{\mathrm{cat}}$ on galactosides. The three mutations, which were far from the active site, were analyzed to test their effect at the structural level. Improved activity on galactosides was induced by the mutations. The S26L and P171L mutations destabilized the enzyme through the removal of a hydrogen bond and increased flexibility of the peptide backbone, respectively. However, the flexibility added by S26L mutation improved the activity at $\mathrm{T}>60{ }^{\circ} \mathrm{C}$. This study shows that random mutagenesis and biological selection allowed the identification of residues that are critical in determining thermal activity, stability, and substrate recognition.
\end{abstract}

Keywords: carbohydrate active enzymes; archaea; glycosidase; Sulfolobus solfataricus; Saccharolobus solfataricus

\section{Introduction}

The ability of enzymes to recognize specific substrates and catalyzing reactions remaining stable even at extreme conditions is driven by molecular factors that are only poorly understood. In this regard, enzymes from thermophiles and hyperthermophiles, microorganisms growing at temperatures up to $80^{\circ} \mathrm{C}$ or above, respectively, have been of long standing research interest, because of their ability to promote chemical reactions at temperatures close to the boiling point of water when the majority of enzymes from mesophiles are denatured. Consequently, extensive biochemical and structural studies on thermozymes (enzymes that function at high temperatures) have shown that their stability is not governed by peculiar amino acids, covalent modifications, or structural motifs, but rather by subtle redistributions of the same intramolecular interactions that are required to stabilize proteins from mesophiles (for reviews, see the literature [1-5]).

In thermozymes, these interactions allow both a balance between molecular stability to avoid unfolding at very high temperatures and the flexibility to promote catalysis at a metabolically 
appropriate rate. However, thermozymes persist for a long time during incubation at high temperatures (thermal stability), and increase their catalytic rate with temperature (thermal activity or thermophilicity). In particular, thermozymes need high temperatures to have specific activity comparable to that of mesozymes at $37^{\circ} \mathrm{C}$. Comparisons of homologous enzymes from organisms spanning a wide range of thermal habitats show that adaptive mutations maintain a balance between thermal stability and activity, regardless of the temperature at which the enzyme operates [1].

Despite extensive studies, the identification of the molecular interactions that are responsible for these properties remained elusive. Most studies aimed to increase the thermal stability of mesozymes through rational design and enzyme engineering or random mutagenesis and appropriate selection methods to obtain new catalysts for biotechnological applications [6-9]. Even fewer examples exist of the laboratory evolution of thermozymes adapted to operational temperatures lower than their normal range of physiological conditions [10,11].

The objective of this work was to analyze whether and how the substrate specificity, thermal activity, and resistance to heat of a thermozyme are bound at the molecular level by combining random mutagenesis and in vivo selection of mutants in a mesophilic host. Thus, the selective pressure might mimic that encountered during natural evolution more closely. To this aim, we focused on a glycoside hydrolase from an Archaeon, as these thermozymes are easy to assay and have interesting biotechnological applications [12-15].

The model system in this study is the $\beta$-glycosidase from Saccharolobus solfataricus-previously Sulfolobus solfataricus-(Ss $\beta$-gly). This enzyme, belonging to family 1 (GH1) of carbohydrate active enzymes (CAZy) classification (www.cazy.org [16]), which was firstly discovered by our group and extensively characterized [17-20], is a well-known model system for studies of molecular stabilization and catalysis engineering. In fact, studies on this enzyme allowed the identification of general structural and functional elements that make thermozymes more stable than mesozymes [21,22]. In particular, ion-pair networks between protein domains and subunits were identified as major players of the molecular stabilization and resilience of thermozymes [23-28]. In addition, studies on Ss $\beta$-gly allowed us to demonstrate that the activity and stability of enzymes can be restored by small molecules that bind to allosteric sites $[29,30]$.

Ss $\beta$-Gly catalyzes a single-substrate reaction by promoting the hydrolysis of $\beta$-D-O-glycosides, including disaccharides (laminaribiose, cellobiose, and lactose) and aryl-glycosides (substituted nitrophenyl- $\beta$-D-gluco-, galacto-, fuco, and xylosides), thereby showing wide substrate specificity [31]. The simple retaining reaction mechanism followed by this enzyme and its versatility has allowed for extensive protein engineering studies that have led to mutants with different substrate specificity [32,33]. The modification of Ss $\beta$-gly active site residues changed the reaction mechanism [34] and allowed the production of a novel class of enzymes, named glycosynthases, that promote the synthesis, rather than then hydrolysis, of oligosaccharides [35-37]. These fundamental studies led to the development of many other glycosynthases of technological interest [38-43].

The number of catalytic studies on $S s \beta$-gly, its well-known reaction mechanism, and the availability of mutants and of several three-dimensional (3D) structures at a high resolution [22,23,34,44,45] prompted us to study the relationship between substrate specificity, catalysis at a high temperature, and structural stability. We addressed this issue by following a non-rational approach exploiting random mutagenesis and in vivo selection of mutants. This was made possible because the lacS gene, encoding for $S s \beta$-gly, cannot promote the growth on lactose minimal medium of an Escherichia coli strain lacking the endogenous lac $Z$ gene. We wanted to test whether random mutations on a thermozyme from a hyperthermophilic Archaeon $\left(\mathrm{T}_{\text {growth }}=80^{\circ} \mathrm{C}\right.$ ), easily and quickly produced by a chemical mutagen, could lead to novel functional $\beta$-galactosidase(s) able to promote growth of a bacterium at $37^{\circ} \mathrm{C}$ on lactose as a unique carbon source. The in vivo selection is expected to affect, simultaneously, the substrate specificity and thermal activity of the enzyme, as lactose is a non-preferred substrate of Ss $\beta$-gly, the catalyze reaction of which occurs at $\mathrm{T}>80^{\circ} \mathrm{C}[20,31]$. The remarkable $S s \beta$-gly stability, 
about 500 min half-life at $75{ }^{\circ} \mathrm{C}$ [20], should not be directly affected by the selection method, but may be a side effect if thermal activity and stability are interconnected.

By following this approach, we report here that the selection of a $S s \beta$-gly mutant library led to a triple mutant, named H7, able to complement a deficient strain of E. coli. The three mutations, S26L, $\mathrm{P} 171 \mathrm{~L}$, and $\mathrm{A} 235 \mathrm{~V}$, were in regions of the enzyme far from the active site, which could not be planned if one would rationally design an improved $\beta$-galactosidase activity. $\mathrm{H} 7$ catalyzed the hydrolysis of lactose 1.8 -fold faster than the wild type, and, surprisingly, at $85^{\circ} \mathrm{C}$, was 2 -fold more active than the wild type and less stable at $75^{\circ} \mathrm{C}$ and $85^{\circ} \mathrm{C}$ by 23 -fold and 283 -fold, respectively. The characterization of single and double mutants and the inspection of $S s \beta$-gly 3D-structure models allowed hypothesizing some explanations to rationalize the effect of the mutations. The results are also discussed in term of the selective pressure produced by the molecular evolution method used.

\section{Results and Discussion}

\subsection{Production of Ss $\beta$-gly Complementing Growth on Lactose at $37^{\circ} \mathrm{C}$}

The pGEX-K-Gly plasmid containing the Saccharolobus solfataricus $\beta$-glycosidase gene (lacS) was subjected to a reaction of chemical mutagenesis with hydroxylamine. This mutagen is known to cause transitions on the type $\mathrm{C} \rightarrow \mathrm{T}$ DNA [46]. The set of mutated genes was isolated from the plasmid and inserted in an untreated plasmid to avoid any mutagenic affects to the other regions (promoter, antibiotic resistance, replication origin, etc.).

This random library was used to transform the E. coli M5154 strain, which has a large deletion on the lactose operon that, unlike the commercial E. coli strains, affects only the $\beta$-galactosidase gene (lacZ) and not the sugar permease (lacY). This makes this strain unable to metabolize lactose as a sole carbon source, even in the presence of the sugar in the cytoplasm. Thus, E. coli M5154 can grow in lactose minimal medium, only if an active $\beta$-galactosidase is also expressed. The selection thus concerned only the clones bearing $S s \beta$-gly mutants able to promote growth faster than the wild type enzyme that complemented this E. coli strain after 10 days at $37^{\circ} \mathrm{C}$ in a lactose minimal medium.

The cells transformed with the plasmid library were plated on rich solid medium containing 5-bromo-4-chloro-3-indolyl- $\beta$-D-glucopyranoside (X-Glc) chromogenic substrate to verify the efficiency of the random mutagenesis. The presence of blue and white colonies ensured that the mutagen had an effect resulting in inactive $S s \beta$-gly mutants. Then, the same cells transformed with the mutant library were plated on minimal solid medium containing lactose as the sole carbon source and incubated at $37^{\circ} \mathrm{C}$. The colonies appearing before the wild type control were identified and chosen. The screening of $>6000$ clones led to the selection of 39 colonies that were isolated and grown on rich liquid medium. Cells were assayed for $\beta$-galactosidase activity on 2-nitrophenyl- $\beta$-D-galacto- and glucopyranoside substrates (2Np-Gal and 2Np-Glc, respectively), and the calculated enzymatic units were compared to those of the wild type enzyme in the same conditions (see Section 3). This analysis led to a further selection of six clones from the starting 39, and one specific mutant, called Ss $\beta$-gly-H7, hereinafter H7, was characterized in detail.

The H7 gene was completely sequenced: as expected, using the hydroxylamine mutagenic agent, three $\mathrm{C} \rightarrow \mathrm{T}$ transitions were found, leading to three aminoacid substitutions; namely, S26L, P171L, and A235V. From the analysis of the three-dimensional structure of $S s \beta$-gly, all of them were located far from the active site at $23 \AA$ (S26), $25 \AA$ (P171), and $18 \AA$ (A235), respectively (Figure 1). S26L and P171L were on the surface of the protein, while A235V was completely buried. Wild type lacS and H7 genes were expressed in E. coli strain BL21(DE3)RIL, fused to glutathione S-transferase, as described in Materials and Methods, and the purified enzymes were characterized in detail. Similarly, S26L, P171L, and A235V single mutants, as well as S26L/P171L, S26L/A235V, and P171L/A235V double mutants, were prepared by subcloning procedures. The corresponding genes were expressed and the recombinant enzymes purified to determine the single contribution of each identified mutation (see Materials and Methods). 


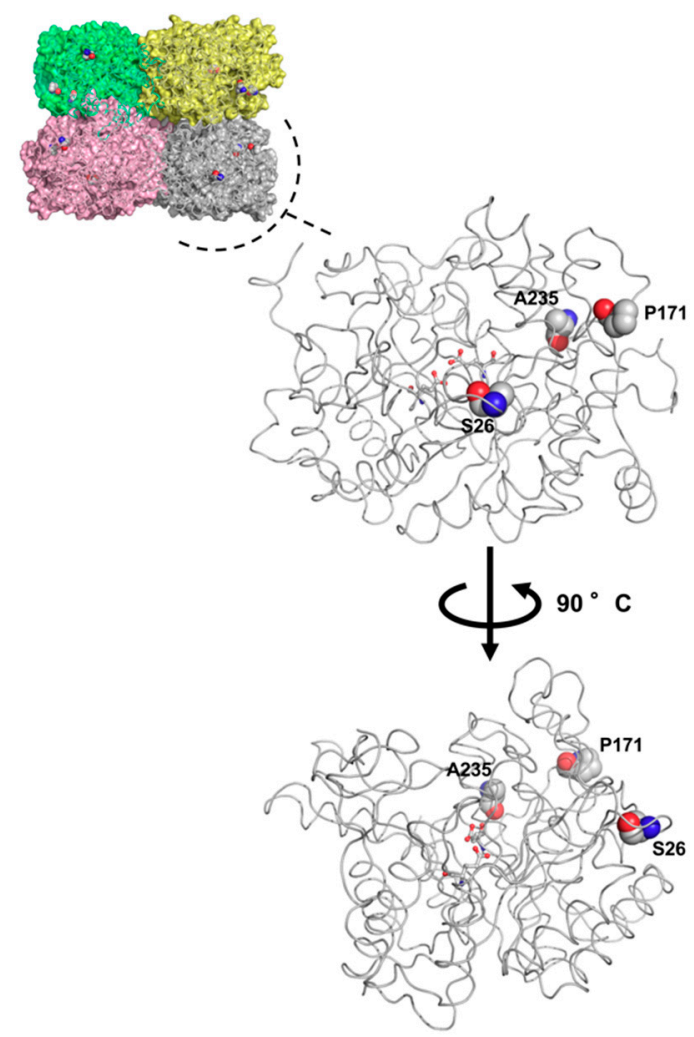

Figure 1. The aminoacid residues mutated in the Saccharolobus solfataricus (Ss $\beta$-Gly) H7 enzyme. The position of S26, P171, and A235 residues (in spherical format) are shown on the tetrameric and monomeric 3D structures of $S s \beta-G l y$, represented in ribbon format. Catalytic residues in the active site are highlighted in ball and stick format, and all atoms are colored by the CPK convention.

\subsection{Steady State Kinetic Constants of the H7 and Relative Single and Double Mutants}

The kinetic parameters at $65^{\circ} \mathrm{C}$ reported in Table 1 show an increase of activity $\left(\mathrm{k}_{\text {cat }}\right)$ by about 2-fold toward the galactose-derived substrates for the $\mathrm{H} 7$ mutant. With $4 \mathrm{~Np}$-Gal, the $\mathrm{K}_{\mathrm{M}}$ values are moderately affected with respect to the wild type; consequently, a relative increase in the catalytic efficiency $\left(\mathrm{k}_{\text {cat }} / \mathrm{K}_{\mathrm{M}}\right)$ is also observed. The turnover number values of the mutant on $4 \mathrm{~Np}-\mathrm{Glc}$ and cellobiose were similar to the wild type. However, the $\mathrm{k}_{\mathrm{cat}} / \mathrm{K}_{\mathrm{M}}$ on $4 \mathrm{~Np}$-Glc substrate was 3.5 -fold higher than the wild type. By contrast, the increased catalytic efficiency observed on $4 \mathrm{~Np}$-Glc is mainly attributable to the $\mathrm{K}_{\mathrm{M}}$, which is 4-fold lower than that of the wild type. The H7 mutant shows an almost 2-fold decreased affinity toward lactose; consequently, $\mathrm{k}_{\mathrm{cat}} / \mathrm{K}_{\mathrm{M}}$ values are unchanged. Therefore, H7 offered to E. coli M5154 strain the ability of growing faster on lactose thanks to an enhanced turnover number rather than catalytic efficiency. Similar results have been obtained with an evolved indoleglycerol phosphate synthase (IGPS), also from Sulfolobus solfataricus, yielding mutants that complemented E. coli growth thanks to an improved turnover number [10].

As shown in Table 1, only the S26L mutant showed properties comparable to the H7 triple mutant, with both $\mathrm{k}_{\mathrm{cat}}$ and $\mathrm{k}_{\mathrm{cat}} / \mathrm{K}_{\mathrm{M}}$ values for $4 \mathrm{~Np}$-Gal being 2 -fold higher than the wild type and specificity constants for $4 \mathrm{~Np}$-Glc, and cellobiose improved by 2.5 -fold and 1.6-fold, respectively. The other single mutants showed catalytic constant values on all substrates tested similar to or lower than the wild type. Among the single mutants, S26L showed the highest catalytic efficiency on disaccharides, although the $\mathrm{k}_{\text {cat }} / \mathrm{K}_{\mathrm{M}}$ value on lactose is comparable to that of the wild type. 
Table 1. Steady state kinetic constants at $65{ }^{\circ} \mathrm{C}$ of Saccharolobus solfataricus (Ss $\beta$-gly) wild type and mutants.

\begin{tabular}{|c|c|c|c|c|c|c|}
\hline & \multicolumn{3}{|c|}{$4 \mathrm{~Np}-\mathrm{Gal}$} & \multicolumn{3}{|c|}{$4 \mathrm{~Np}-\mathrm{Glc}$} \\
\hline & $\mathrm{K}_{\mathbf{M}}(\mathrm{mM})$ & $k_{\mathrm{cat}}\left(\mathrm{s}^{-1}\right)$ & $\begin{array}{c}k_{\mathrm{cat}} / \mathrm{K}_{\mathrm{M}}\left(\mathrm{s}^{-1}\right. \\
\left.\mathrm{mM}^{-1}\right)\end{array}$ & $\mathrm{K}_{\mathrm{M}}(\mathrm{mM})$ & $k_{\mathrm{cat}}\left(\mathrm{s}^{-1}\right)$ & $\begin{array}{c}k_{\mathrm{cat}} / \mathrm{K}_{\mathrm{M}}\left(\mathrm{s}^{-1}\right. \\
\left.\mathrm{mM}^{-1}\right)\end{array}$ \\
\hline Wild type (S26/P171/A235) & $1.17 \pm 0.15$ & $389.8 \pm 13.25$ & 333.16 & $0.94 \pm 0.22$ & $437.2 \pm 23.4$ & 465.1 \\
\hline H7 (S26L/P171L/A235V) & $1.71 \pm 0.32$ & $908.7 \pm 43.3$ & 530.0 & $0.23 \pm 0.03$ & $376.8 \pm 13.9$ & 1629.0 \\
\hline S26L & $1.56 \pm 0.23$ & $938.9 \pm 33.9$ & 601.8 & $0.36 \pm 0.09$ & $423.8 \pm 20.1$ & 1177.2 \\
\hline$P 171 L$ & $1.39 \pm 0.25$ & $444.5 \pm 18.8$ & 319.8 & $0.44 \pm 0.11$ & $221.6 \pm 10.8$ & 503.6 \\
\hline$A 235 \mathrm{~V}$ & $1.00 \pm 0.11$ & $310.1 \pm 7.9$ & 310.0 & $0.41 \pm 0.08$ & $168.5 \pm 6.1$ & 414.9 \\
\hline S26L/P171L & $2.85 \pm 0.23$ & $93.2 \pm 2.2$ & 32.8 & $0.31 \pm 0.10$ & $34.3 \pm 2.0$ & 109.0 \\
\hline S26L/A235V & $1.20 \pm 0.18$ & $795.7 \pm 27.2$ & 662.0 & $0.44 \pm 0.11$ & $393.1 \pm 19.2$ & 885.7 \\
\hline \multirow[t]{3}{*}{$P 171 L / V 235 V$} & $1.46 \pm 0.13$ & $150.5 \pm 3.2$ & 102.9 & $0.47 \pm 0.11$ & $75.7 \pm 3.6$ & 159.0 \\
\hline & \multicolumn{3}{|c|}{ Lactose } & \multicolumn{3}{|c|}{ Cellobiose } \\
\hline & $\mathrm{K}_{\mathrm{M}}(\mathrm{mM})$ & $k_{\mathrm{cat}}\left(\mathrm{s}^{-1}\right)$ & $\begin{array}{c}k_{\text {cat }} / \mathrm{K}_{\mathrm{M}}\left(\mathrm{s}^{-1}\right. \\
\left.\mathrm{mM}^{-1}\right)\end{array}$ & $\mathrm{K}_{\mathrm{M}}(\mathrm{mM})$ & $k_{\mathrm{cat}}\left(\mathrm{s}^{-1}\right)$ & $\begin{array}{c}k_{\mathrm{cat}} / \mathrm{K}_{\mathrm{M}}\left(\mathrm{s}^{-1}\right. \\
\left.\mathrm{mM}^{-1}\right)\end{array}$ \\
\hline Wild type (S26/P171/A235) & $137.7 \pm 6.2$ & $710.8 \pm 9.6$ & 5.2 & $33.2 \pm 5.12$ & $274.7 \pm 12.9$ & 8.3 \\
\hline H7 (S26L/P171L/A235V) & $245.5 \pm 20.4$ & $1270.8 \pm 40.7$ & 5.2 & $33.6 \pm 6.7$ & $372.5 \pm 22.1$ & 11.1 \\
\hline$S 26 L$ & $118.2 \pm 5.1$ & $505.0 \pm 7.2$ & 4.3 & $18.3 \pm 3.2$ & $252.2 \pm 11.0$ & 13.8 \\
\hline$P 171 L$ & $140.4 \pm 20.4$ & $308.6 \pm 15.7$ & 2.2 & $20.6 \pm 2.7$ & $122.2 \pm 4.0$ & 5.9 \\
\hline$A 235 \mathrm{~V}$ & $149.6 \pm 10,3$ & $226.6 \pm 5,5$ & 1.5 & $18.3 \pm 1.0$ & $95.1 \pm 1.4$ & 5.2 \\
\hline S26L/P171L & $144.8 \pm 7.6$ & $84.2 \pm 1.5$ & 0.6 & $30.7 \pm 4.2$ & $36.5 \pm 1.4$ & 1.2 \\
\hline$S 26 L / A 235 V$ & $120.0 \pm 12.6$ & $510.2 \pm 17.6$ & 4.3 & $80.4 \pm 21.4$ & $374.8 \pm 36.5$ & 4.7 \\
\hline P171L/V235V & $161.9 \pm 8.7$ & $119.0 \pm 2.3$ & 0.7 & $55.6 \pm 10.0$ & $68.0 \pm 4.4$ & 1.2 \\
\hline
\end{tabular}

The $\beta$-glycosidase from the hyperthermophilic archaeon Pyrococcus furiosus (CelB), also belonging to family GH1, once evolved on $4 \mathrm{~Np}$-Glc at room temperature, showed a three-fold improved rates of hydrolysis by single mutations in the active site [11]. In the Ss $\beta$-gly H7 mutant, instead, S26L, P171L, and A235V mutations were all far from the active site. The superimposition of the 3D-structure of Ss $\beta$-gly and the derived model of the triple mutant did not show any difference in the residues of the active site (not shown). The distance from the active site did not allow us to find easy explanations on the molecular reasons of the ability of H7 to promote lactose hydrolysis faster than the wild type. Potentially, increasing the flexibility of the structure in the mutation sites led to conformational changes that were transferred to the active site and improved the conversion of galactose-derived substrates. Mutations influencing enzyme function even at a distance from the catalytic residues may be not uncommon, as proteins often undergo conformational changes during the reaction [47] and long distance effects play important roles in enzyme function, as recently reviewed in the work of [48]. Rational protein engineering experiments on the amino acids located in the active site region broadened the substrate specificity of $S s \beta$-gly $[32,33]$, suggesting that active site modifications would be needed to change the substrate specificity of the enzyme. Therefore, it would be easy to predict that further mutations for improved activity could be found in the same area. Instead, we showed here that substitutions not restricted to the active site had also some influence, allowing in vivo complementation and significantly enhancing the turnover number and the catalytic efficiency of the enzyme on galactose-derived substrates and 4-Np-Glc, respectively. The different effect observed for $S s \beta$-gly and CelB could be the result of the different approaches used: in vivo selection instead of in vitro screening, respectively. In the former approach, biology exerts a combination of forces not determined only by kinetic and chemical recognition. Our study demonstrates that, at the in vivo selection conditions used, enzyme catalysis of $S s \beta$-gly was determined by the enzyme as a whole.

\subsection{Temperature Dependence of the H7 and Relative Single and Double Mutants}

The effect of temperature on the specific activity on $4 \mathrm{~Np}-\mathrm{Gal}$ by all the mutants followed the same trend of the wild type, increasing continuously up to the maximum of $85^{\circ} \mathrm{C}$, with S26L and the $\mathrm{H} 7$ mutants showing the highest $\mathrm{U} \mathrm{mg}^{-1}$ at all temperatures (Figure 2a,b). The specific activity of the S26L mutant, as single or in combination with $\mathrm{A} 235 \mathrm{~V}$, was maximal at $85{ }^{\circ} \mathrm{C}$, as observed in the triple mutant. Instead, at this temperature, the specific activity values were similar or lower than 
those of the wild type, for the single mutants A235V and P171L and the double mutants P171L/A235V and P26L/P171L, respectively (Figure 2a,b). This is someway surprising. For the known rule 'you get what you screen for [49], and based on previous studies on CelB [11], it might be expected that the selection at $37^{\circ} \mathrm{C}$ could result in increasing specific activity at mesophilic temperatures, possibly reducing the activity at $85^{\circ} \mathrm{C}$. Instead, selective pressure increased the specific activity of the mutant at temperatures $>50{ }^{\circ} \mathrm{C}$, where the upward shift of the curve was not constant, but increased with temperature (Figure 2a). This resembles the behaviour of the mutants of a thermophilic esterase after several directed evolution generations [50].

a

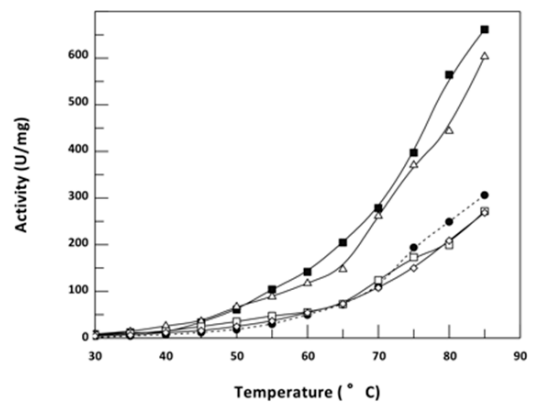

C

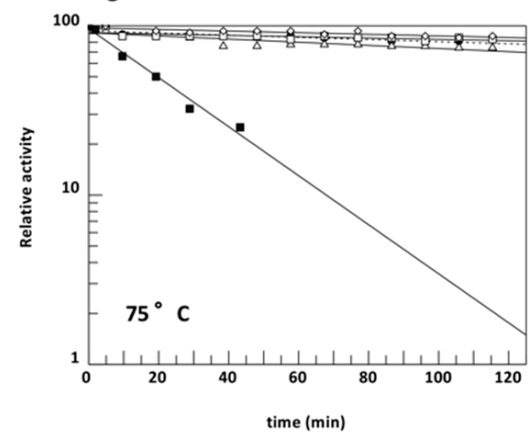

time $(\min )$
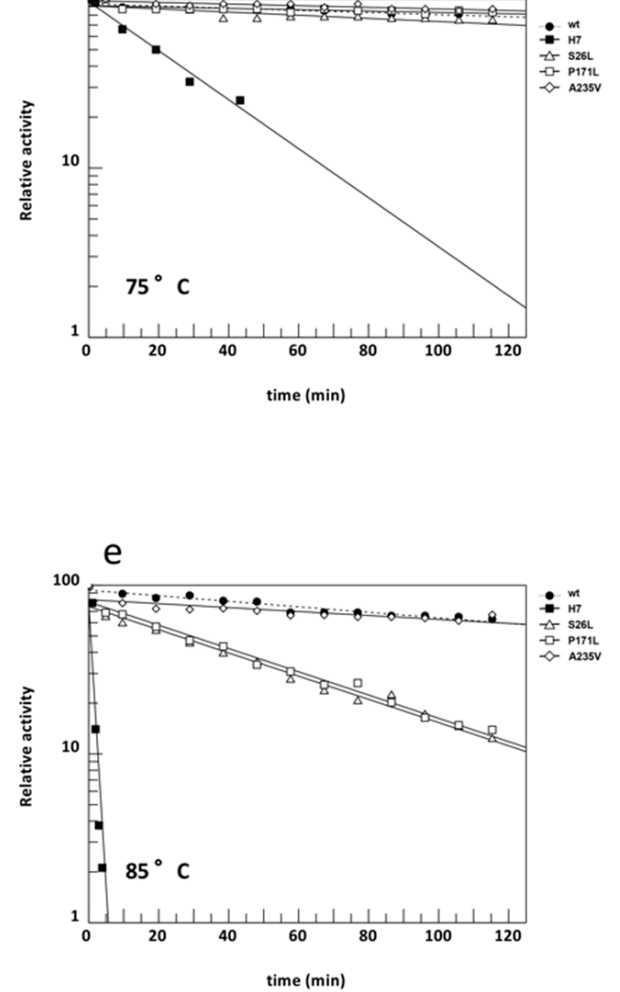

b

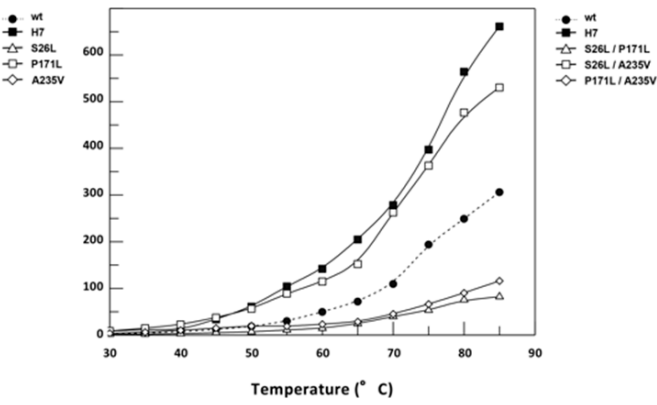

d

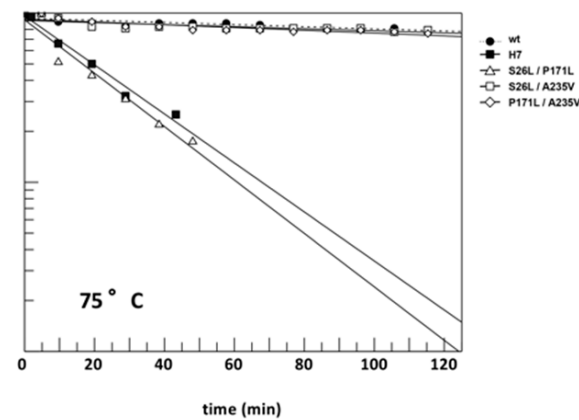

$f$

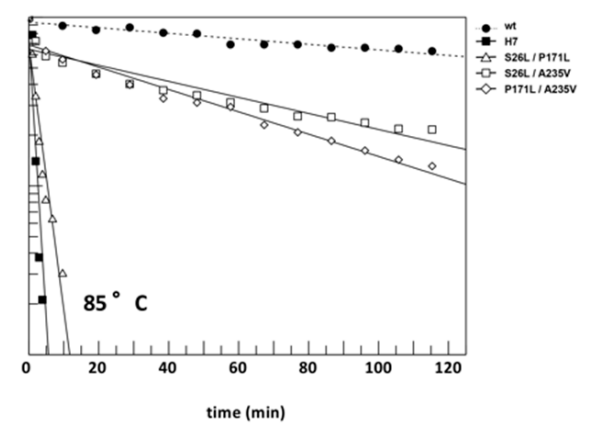

Figure 2. Thermal activity and stability of $S s \beta-G l y H 7$ and relative single and double mutants. The dependence on temperature of the wild type is compared with the $\mathrm{H} 7$ mutant; single (a) and double mutants (b). Similarly, the residual activity at $75^{\circ} \mathrm{C}$ and $85^{\circ} \mathrm{C}$ of the wild type, in comparison with $\mathrm{H} 7$ mutant, single (c,e) and double mutants $(\mathbf{d}, \mathbf{f})$, is reported. Ss $\beta$-Gly (closed circles on dotted line); Ss $\beta$-Gly H7 (closed squares); L26 (open triangles); L171 (open squares); V235 (open diamonds); L26/L171 (open triangles); L26/V235 (open squares); L171/V235 (open diamonds). 
The effect of the mutations on $S s \beta$-gly was detrimental on the thermal stability. The $\mathrm{H} 7$ mutant was as stable as the wild type at $\mathrm{T} \leq 65^{\circ} \mathrm{C}$ (data not shown), but 23-fold and 283-fold less stable at $75{ }^{\circ} \mathrm{C}$ and $85^{\circ} \mathrm{C}$, respectively (Figure $2 \mathrm{c}-\mathrm{f}$, Table 2). The half-lives measured at $75^{\circ} \mathrm{C}$ showed that all single mutations did not significantly alter the enzyme stability with the exception of S26L, which was inactivated 1.5-fold faster than the wild type (Table 2). This is even clearer in the S26L/P171L double mutant, showing the same low stability of $\mathrm{H7}$ (Figure 2c,d). Instead, the same analysis at $85^{\circ} \mathrm{C}$ revealed that only the $\mathrm{A} 235 \mathrm{~V}$ mutant was as stable as the wild type (Figure 2e). All the other mutants showed a $t_{\frac{1}{2}}$ from 5.5 -fold to 284 -fold lower than the wild type $S s \beta$-gly under these conditions (Table 2). Again, the S26L/P171L double mutant is similar to H7 (Figure 2f).

Table 2. Half-life of $S s \beta$-gly wild type and mutants at $75^{\circ} \mathrm{C}$ and $85^{\circ} \mathrm{C}$.

\begin{tabular}{|c|c|c|c|}
\hline \multirow{2}{*}{ Mutants } & \multicolumn{2}{|c|}{$\mathbf{t}_{\frac{1}{2}}(\min )$} & \multirow{2}{*}{ Symbols Used in Figure 2} \\
\hline & $75^{\circ} \mathrm{C}$ & $85^{\circ} \mathrm{C}$ & \\
\hline $\begin{array}{c}\text { Wild type } \\
\text { (S26/P171/A235) }\end{array}$ & $461.3 \pm 78.0$ & $170.4 \pm 10.7$ & \\
\hline H7 (S26L/P171L/A235V) & $20.5 \pm 1.5$ & $0.6 \pm 0.1$ & \\
\hline S26L & $299.4 \pm 68.2$ & $26.6 \pm 1.2$ & \\
\hline P171L & $681.1 \pm 175.7$ & $30.7 \pm 1.4$ & \\
\hline $\mathrm{A} 235 \mathrm{~V}$ & $580.8 \pm 10.5$ & $200.9 \pm 37.1$ & \\
\hline S26L/P171L & $17.4 \pm 2.4$ & $0.9 \pm 0.1$ & - \\
\hline S26L/A235V & $465.7 \pm 164.2$ & $24.4 \pm 2.7$ & \\
\hline P171L/A235V & $335.8 \pm 42.3$ & $21.8 \pm 1.4$ & \\
\hline
\end{tabular}

The inspection of the H7 mutant 3D-model (Figure 3) allowed the explanation of these results. The mutations increased the entire hydrophobicity of the protein and removed specific stabilizing interactions. Residues with low hydrophobicity index (Ser $=-0.8$; Pro $=-1.8 ; \mathrm{Ala}=1.8$ ) were substituted with amino acids that are highly hydrophobic (Leu $=3.8 ; \mathrm{Val}=4.2)$ [51]. The substitution of Ser26 with a leucine increased the hydrophobicity in the loop region encompassing Met21 and Gly22 (Figure $3 \mathrm{a}, \mathrm{b}$ ) and removed a hydrogen-bond with the peptide nitrogen of Gly22 and the carbonyl oxygen of Thr23. In addition, the replacement of the polar S26 residue exposed to the solvent with a non-polar leucine led to a local destabilization of the protein structure, observable at temperatures $>80^{\circ} \mathrm{C}$. However, interestingly, this increased flexibility explains the high thermophilicity of the S26L mutant (Figure 2a). 
a

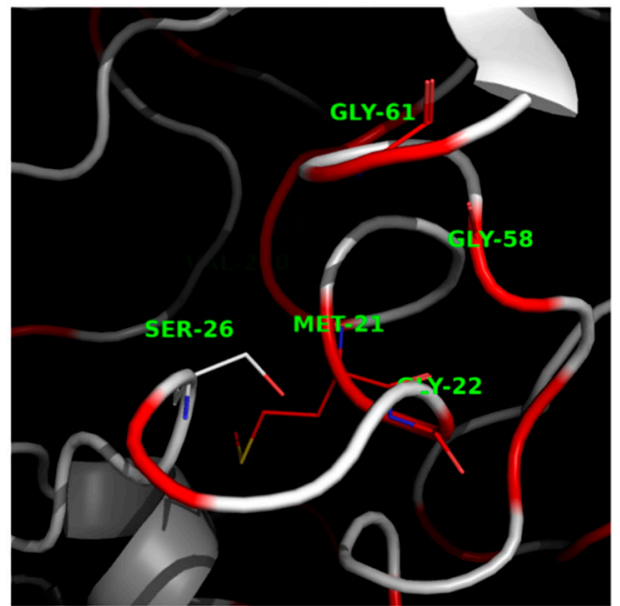

C

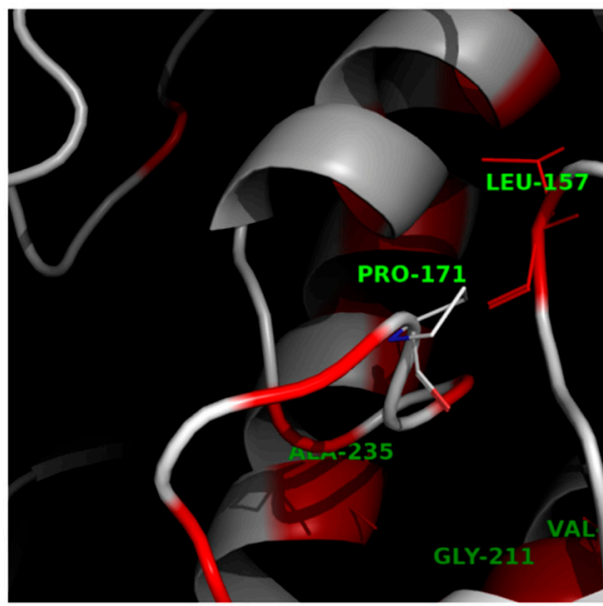

e

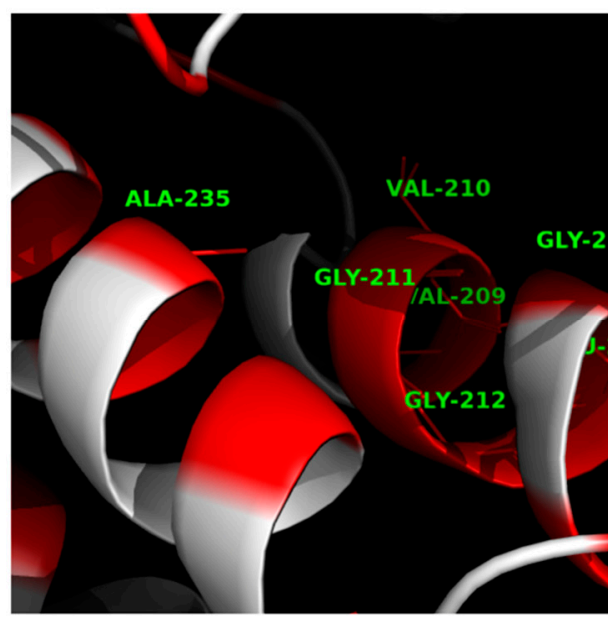

b

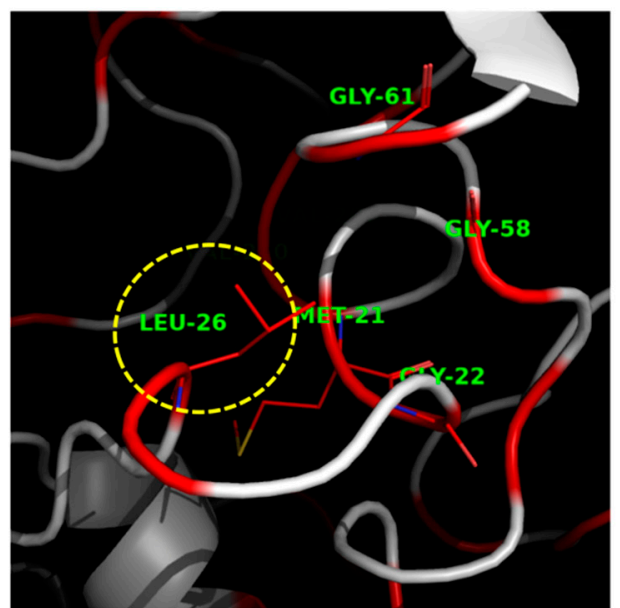

d

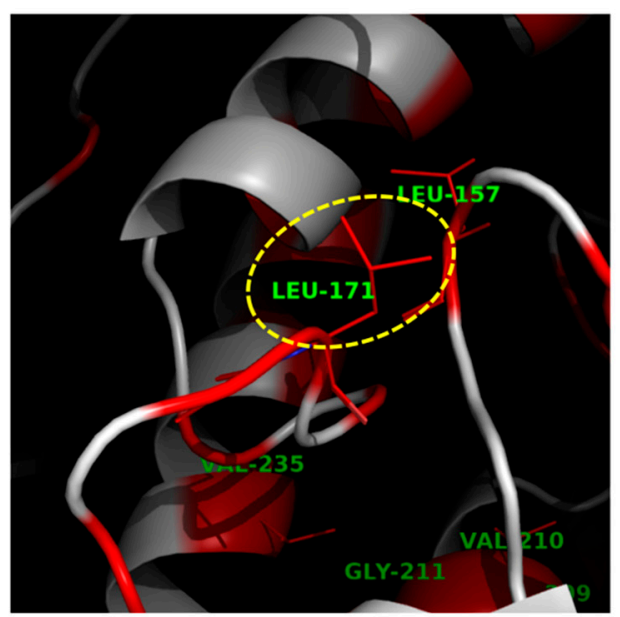

f

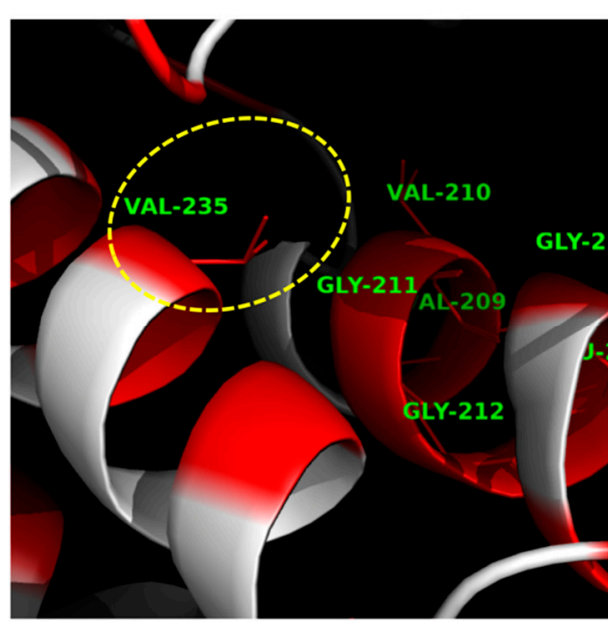

Figure 3. Ss $\beta$-Gly 3D structure in comparison with the $\mathrm{H} 7$ mutant model. Close-up of Ss $\beta$-Gly wild type structure (PDB ID: 1GOW) (a,c,e) and $S s \beta$-Gly single mutations in the H7 mutant, S26L, P171L, and $\mathrm{A} 235 \mathrm{~V}$ in $(\mathbf{b}, \mathbf{d}, \mathbf{f})$, respectively. The hydrophobic residues are indicated in red. The mutant residues are highlighted in yellow.

The substitution of the Pro171 with a leucine residue (P171L) in the extended loop Arg165-Thr177 exposed to the solvent (Figure 3c,d) explained the destabilizing effect in the nearby hydrophobic environment involving the $\alpha 4$-helix (Ser228-Lys255), the small $\alpha$-helix (Pro207-Val206), and the loop Asn147-Pro160 (Figure 3e,f). When we modelled in the structure the substituting leucine, the proline cis configuration was removed (Figure $3 \mathrm{~d}$ ) and the local flexibility increased, thus destabilizing the 
structure at $85^{\circ} \mathrm{C}$ (Figure 2e). Interestingly, the destabilizing effect of the S26L and P171L mutations is additive, indicating that they are responsible for the instability of the triple mutant H7 (Figure 2f).

According to the $S s \beta$-gly 3D structure, A235 is located inside of the $\alpha 4$-helix and is very close to the small $\alpha$-helix Pro207-Val216 [23]. The lack of destabilization by the A235V mutation could be explained by the similarity between these two residues, which does not affect the formation of the $\alpha$-helix despite the greater steric hindrance of a valine residue. On the other hand, V235, showing a longer side chain when compared with the wild type alanine, might affect the optimal packing by protruding on the side of the helix. However, the increased local hydrophobicity could, in part, balance this negative effect, explaining why A235V showed the same thermostability at $85^{\circ} \mathrm{C}$ as the wild type (Figure 3e).

The instability of the A235V-containing double mutants is clearly attributable to the detrimental contribution of the other mutations (Table 2; Figure 2d,f). The presence of the three mutations on the surface of $S s \beta$-gly, and the fact that they do not seem to interact with each other, may indicate that the mutations act independently on different regions of the protein promoting the unfolding at $\mathrm{T}>75^{\circ} \mathrm{C}$, thereby affecting the overall stability. In the case of P171L mutation, possibly, an increased flexibility may have made the $\mathrm{H} 7$ triple mutant more active than the wild type at all temperatures tested.

It is worth noting that the triple mutant is more active than its wild-type progenitor at all temperatures, but rapidly became inactivated at $85^{\circ} \mathrm{C}$. Directed evolution studies in which enzymes were adapted to different temperatures often led to the conclusion that there is a trade-off between catalytic activity at low temperatures and thermostability, explained as the balance to maintain the rigidity necessary for stability and the flexibility required for enzyme activity. However, this is not always the case; indeed, the evolved CelB with optimized substrate specificity and gained catalytic activity at $20^{\circ} \mathrm{C}$ showed reduced activity at $\mathrm{T}>80{ }^{\circ} \mathrm{C}$ and destabilization [11], and an evolved glucokinase from a thermophilic fungus showed both improved stability under heat and thermophilicity when compared with the wild type [52]. Laboratory evolution experiments can identify different adaptive mechanisms, but these can be achieved by exploring a limited number of protein fitness pathways often dependent on the selection method used [49,53]. In this study, we applied an in vivo selection, in which mutants complementing an E. coli mutant were isolated. The same approach on IGPS from S. solfataricus yielded mutants that improved growth appreciably, with activity increasing with temperature and accelerated thermal denaturation as observed here for evolved $S s \beta$-gly [10]. Selecting enzyme properties through survival and growth of the host organism, unlike in vitro screenings, exerts a biological function that could be dictated not only by physical and chemical laws, but also by biological natural selection [53]. Possibly, the reduced stability observed for evolved $S s \beta$-gly may allow its quicker protein turnover within the E. coli mesophilic cell that could be required to complement the lacking $\beta$-galactosidase activity. Conversely, the improved activity of the $\mathrm{H} 7$ mutant at temperatures where $\mathrm{S}$. solfataricus grows optimally $\left(85^{\circ} \mathrm{C}\right)$ could merely be the consequence of $\mathrm{E}$. coli being more active at $37^{\circ} \mathrm{C}$ and might not fit in archaeal cells by interfering with the normal physiology of this organism.

\section{Materials and Methods}

\subsection{Reagents}

All commercially available substrates were purchased from Sigma. Restriction endonucleases and T4 DNA ligase were from New England BioLabs, USA. Synthetic oligonucleotides were from PRIMM (Milan, Italy). Escherichia coli M5154 strain was from the Coli Genetic Stock Center (Yale University, USA).

\subsection{Random Mutagenesis}

The pGEX-2TK-derivative (GE Healthcare, USA) plasmid (pGEX-K-Gly) containing the wild type $S$. solfataricus $\beta$-glycosidase gene (lacS) was described previously [54]. Random mutagenesis was performed by chemical treatment of the pGEX-K-Gly plasmid with hydroxylamine. In particular, 
$\sim 15.0 \mu \mathrm{g}$ of the plasmid was denatured with $\mathrm{NaOH} 0.2 \mathrm{M}$ at room temperature for $5 \mathrm{~min}$, followed by a fast neutralization step with ammonium acetate at $\mathrm{pH}$ 7.5. Finally, the plasmid was exposed to hydroxylamine $\left(\mathrm{H}_{3} \mathrm{NO}\right) 0.5 \mathrm{M}$ at $37^{\circ} \mathrm{C}$ for $8.0 \mathrm{~h}$ in phosphate buffer $50.0 \mathrm{mM} \mathrm{pH} 6.5$. The $\sim 1500 \mathrm{bp}$ DNA fragment relative to the lacS gene was purified by gel extraction, after digestion of the treated pGEX-K-Gly plasmid using the Bam HI and Sma I restriction enzymes. A library of random mutants was obtained by a ligation of the lacS gene with a Bam HI-Sma I linearized pGEX-2TK plasmid.

\subsection{Selection of Ss $\beta$-gly Mutants for Enhanced Lactose Hydrolysis}

A ligation mixture was utilized for the transformation of the E. coli M5154 strain, which harbours a deletion of almost one-third of the lacZ gene ( $\Delta$ lacZ39 deletion), making this strain completely inactive for the hydrolysis of galactose-derived $\beta$-substrates. For the screening, we exploited the $\beta$-glucosidase activity of the product of the lacS gene. E. coli M5154 cells transformed with the library of random mutants were first plated on $50 \mu \mathrm{g} / \mathrm{mL}$ ampicillin (Amp) LB Agar medium containing the 5-bromo-4-chloro-3-indolyl- $\beta$-D-glucopyranoside (X-Glc) chromogenic substrate, and the mutagenic impact of the hydroxylamine treatment was thus determined by calculating the blue/white colony ratio. Afterwards, transformed cells were plated on M9 Amp Trp minimal medium, containing lactose as the sole carbon source, and incubated at $37^{\circ} \mathrm{C}$. Wild type lacS expressing clones led to colonies after about 10 days of incubation because of the basal $\beta$-galactosidase activity of the enzyme. All colonies appearing before, namely after six to seven days of incubation, were identified and picked. Selected colonies were grown in rich medium and analyzed for their $\beta$-galacto- and $\beta$-glucosidase activity, by using a colorimetric enzymatic assay and 2Np-Gal and 2Np-Glc, respectively, as substrates [55].

\subsection{Production of H7-Derived Single and Double Mutants}

The in vivo selected $\mathrm{H} 7$ clone was sequenced and three mutations were identified (S26L, P171L, and $\mathrm{A} 235 \mathrm{~V})$. The opportunity that unique restriction sites in the lacS gene separate these mutations allowed for the preparation of specific DNA fragments containing single and/or double mutations. These were combined and ligated with the opportunely digested pGEX-K-Gly plasmids to finally achieve the $S s \beta$-gly single and double mutants.

\subsection{Enzyme Expression and Purification}

Wild-type Ss $\beta$-gly and relative mutants were expressed and purified as fusions of glutathione S-transferase (GST), as previously reported $[36,54,56]$. Briefly, transformed E. coli BL21(DE3)RIL, carrying extra copies of the $\arg U$, ileY, and leuW tRNA genes cells, were grown in SB medium at $37^{\circ} \mathrm{C}$ and induced by the addition of $1.0 \mathrm{mM}$ IPTG, when cultures reached an $\mathrm{OD}_{600}$ of 1.0. After $16 \mathrm{~h}$ of incubation, cells were harvested by centrifugation at $5000 \times g$ and stored at $-20^{\circ} \mathrm{C}$. Then, the pellet was thawed and resuspended in $2.0 \mathrm{~mL} / \mathrm{g}$ cells of PBS buffer $(50.0 \mathrm{mM}$ sodium phosphate buffer, $150.0 \mathrm{mM} \mathrm{NaCl} ; \mathrm{pH} 7.4)$. After French press cell disruption and centrifugation at $4{ }^{\circ} \mathrm{C}$ for $30 \mathrm{~min}$ at $30,000 \times \mathrm{g}$ to discard cell debris, free cell crude extract containing the fusion protein was subjected to an affinity chromatography on a glutathione-Sepharose $4 \mathrm{~B}^{\mathrm{TM}}$ resin (GE Healthcare, USA), followed by an incubation with thrombin protease in order to separate GST and $S s \beta$-gly.

Aliquots of pure proteins ( $>95.0 \%$, as judged by SDS-PAGE analysis) were stored at $-20{ }^{\circ} \mathrm{C}$ in PSB $1 X$ containing $20.0 \%$ glycerol. The samples stored in these conditions are stable for several months. The protein concentration was determined with the method of Bradford, using bovine serum albumin as the standard [57].

\subsection{Enzyme Characterization}

All kinetic studies were performed by following spectrophotometrically the hydrolytic activity with a Cary 100 Scan spectrophotometer (Varian, Australia), coupled with a thermally controlled Peltier system. A total of $1.0 \mathrm{~mL}$ of reaction solution was preheated for $2.0 \mathrm{~min}$, keeping the temperature constant during all measurements. $\beta$-glycosidase activity performed at $65{ }^{\circ} \mathrm{C}$ in $50 \mathrm{mM}$ sodium 
phosphate buffer at $\mathrm{pH} 6.5$ was conventionally defined as the standard reaction. Kinetic parameters at standard conditions were determined using artificial and natural substrates, whose concentration ranged from 0.1 to 30.0 and from 1.25 to $750.0 \mathrm{mM}$, respectively. In order to correct the spontaneous hydrolysis of the substrates, mixtures containing all the reactants except enzymes were prepared and referred to as blank reactions. Steady-state kinetic constants were obtained by plotting initial velocity values versus 15 different substrate concentrations for each substrate. In each assay, amounts ranging from 0.5 to $20.0 \mu \mathrm{g}$ of wild type $S s \beta$-gly and mutants were used. Measuring the hydrolytic activity on 4-nitrophenol based substrates at standard conditions, a molar extinction coefficient $\left(\varepsilon_{\mathrm{M}}\right)$ value of $9340 \mathrm{M}^{-1} \mathrm{~cm}^{-1}$ at $405 \mathrm{~nm}$ was used, whereas the activity on lactose and cellobiose was determined by measuring the released glucose with the glucose oxidase-peroxidase enzymatic assay GOPOD (Megazyme, Chicago, Illinois, USA), taking into account that one molecule of cellobiose leads to the release of two glucose units. One unit of enzyme activity was conventionally defined as the amount of the enzyme that hydrolyses $1.0 \mu \mathrm{mol}$ of substrate in $1.0 \mathrm{~min}$ under standard conditions. All data were plotted and refined using the program GraFit 5.0 (Erithacus Software Ltd., Horley, U.K.), in order to determine the steady-state kinetic parameters.

\subsection{Thermal Stability and Temperature Dependence}

The thermal stability was analyzed by incubating all the enzymes at the concentration of $0.01 \mu \mathrm{g} / \mathrm{mL}$ in $50.0 \mathrm{mM}$ phosphate buffer $\mathrm{pH} 6.5$, at the indicated temperatures and times. The hydrolytic activity of each sample was determined at $405 \mathrm{~nm}$ in standard conditions, using a molar extinction coefficient $\left(\varepsilon_{\mathrm{M}}\right)$ value of $9340 \mathrm{M}^{-1} \mathrm{~cm}^{-1}$ for the release of 4-nitrophenol. The activity of the sample measured without any incubation was taken as $100 \%$.

Enzymes were assayed in standard conditions from 30 to $85{ }^{\circ} \mathrm{C}$, in order to evaluate their temperature dependence. Enzymatic units were measured using different molar extinction coefficient values, as follows: $6130 \mathrm{M}^{-1} \mathrm{~cm}^{-1}\left(30^{\circ} \mathrm{C}\right) ; 6570 \mathrm{M}^{-1} \mathrm{~cm}^{-1}\left(35^{\circ} \mathrm{C}\right) ; 6910 \mathrm{M}^{-1} \mathrm{~cm}^{-1}\left(40^{\circ} \mathrm{C}\right) ; 7530 \mathrm{M}^{-1} \mathrm{~cm}^{-1}$ $\left(45^{\circ} \mathrm{C}\right) ; 7970 \mathrm{M}^{-1} \mathrm{~cm}^{-1}\left(50{ }^{\circ} \mathrm{C}\right) ; 8420 \mathrm{M}^{-1} \mathrm{~cm}^{-1}\left(55^{\circ} \mathrm{C}\right) ; 8890 \mathrm{M}^{-1} \mathrm{~cm}^{-1}\left(60^{\circ} \mathrm{C}\right) ; 9340 \mathrm{M}^{-1} \mathrm{~cm}^{-1}\left(65^{\circ} \mathrm{C}\right)$; $9700 \mathrm{M}^{-1} \mathrm{~cm}^{-1}\left(70{ }^{\circ} \mathrm{C}\right) ; 10120 \mathrm{M}^{-1} \mathrm{~cm}^{-1}\left(75^{\circ} \mathrm{C}\right) ; 10610 \mathrm{M}^{-1} \mathrm{~cm}^{-1}\left(80^{\circ} \mathrm{C}\right) ; 10900 \mathrm{M}^{-1} \mathrm{~cm}^{-1}\left(85^{\circ} \mathrm{C}\right)$.

\subsection{D-Model of Ss $\beta$-gly H7 Mutant}

Homology modeling of $S s \beta$-gly H7 mutant structure was performed by SWISS-MODEL server [58] using the $S s \beta$-gly wild type structure (PDB entry 1gow) as a template. Stereochemical quality of the model was analyzed by the PROCHECK program and PyMol 1.0 was used to analyze and visualize the structure [59].

\section{Conclusions}

In this study, we identified residues that are critical in determining the thermostability, thermal activity, and substrate specificity of the studied thermozyme $S s \beta$-gly. In previous rationally designed protein engineering studies on $S s \beta$-gly, mutants in the active site showed broadened substrate specificity. Here, three mutations far from the active site obtained randomly after an in vivo selection produced a more than two-fold enhancement of the specific activity at $85{ }^{\circ} \mathrm{C}$ and of the $\mathrm{k}_{\text {cat }}$ on galactoside substrates. Interestingly, the activity of the enzyme on cellobiose remained the same as the wild type or was even enhanced on 4-Np-Glc. This remarkable result was paid off with a 283 -fold reduced thermal stability, when compared with the wild type. The change of Ser26 into Leu enhanced the thermophilicity because of the disruption of stabilizing interactions that, by increasing the flexibility of the enzyme, facilitated catalysis at a high temperature, but also weakened its resistance to heat. Our study shows that it is not always successful to improve the enzyme activity following a "rational" approach based on the known and understood physicochemical laws that determine the conformations and interactions of the amino acids and enzyme catalysis. When possible, "irrational" approaches, which exploit in vivo selection, can produce enzyme mutants of interest. 
Author Contributions: G.P. contributed to conceptualization, investigation, and writing-review and editing; A.S. contributed to formal analysis, data curation, and writing-review and editing; M.M. (Marialuisa Mazzone) contributed to formal analysis; M.R. contributed to supervision; M.M. (Marco Moracci) contributed to conceptualization; funding acquisition, and writing —original draft preparation.

Funding: This research was funded by a grant from the Ministero dell'Università e della Ricerca Scientifica Industrial Research Project “Development of green technologies for production of BIOchemicals and their use in preparation and industrial application of POLImeric materials from agricultural biomasses cultivated in a sustainable way in Campania region-BioPoliS" PON03PE_00107_1/1, funded in the frame of Operative National Programme Research and Competitiveness 2007-2013 D. D. Prot. n. 713/Ric. 29.10.2010.

Acknowledgments: We are grateful to Chiara Nobile and Marco Petruzziello at the Institute of Biosciences and BioResources (IBBR) from the National Research Council of Italy for administrative and technical assistance, as well as to Karl Joseph Duffy (PhD) of the Department of Biology, University of Naples "Federico II" for the editing of the manuscript.

Conflicts of Interest: The authors declare no conflict of interest.

\section{References}

1. Fields, P.A. Review: Protein function at thermal extremes: Balancing stability and flexibility. Comp. Biochem. Physiol. A: Mol. Integr. Physiol. 2001, 129, 417-431. [CrossRef]

2. $\quad$ Littlechild, J.A.; Guy, J.; Connelly, S.; Mallett, L.; Waddell, S.; Rye, C.A.; Line, K.; Isupov, M. Natural methods of protein stabilization: Thermostable biocatalysts. Biochem. Soc. Trans. 2007, 35, 1558-1563. [CrossRef]

3. Imanaka, T. Molecular bases of thermophily in hyperthermophiles. Proc. Jpn. Acad. Ser. B Phys. Biol. Sci. 2011, 87, 587-602. [CrossRef] [PubMed]

4. Pica, A.; Graziano, G. Shedding light on the extra thermal stability of thermophilic proteins. Biopolymers 2016, 105, 856-863. [CrossRef]

5. Vieille, C.; Zeikus, G.J. Hyperthermophilic enzymes: Sources, uses, and molecular mechanisms for thermostability. Microbiol. Mol. Biol. Rev. 2001, 65, 1-43. [CrossRef]

6. Ito, Y.; Ikeuchi, A.; Imamura, C. Advanced evolutionary molecular engineering to produce thermostable cellulase by using a small but efficient library. Protein Eng. Des. Sel. 2013, 26, 73-79. [CrossRef]

7. Ruller, R.; Alponti, J.; Deliberto, L.A.; Zanphorlin, L.M.; Machado, C.B.; Ward, R.J. Concommitant adaptation of a gh11 xylanase by directed evolution to create an alkali-tolerant/thermophilic enzyme. Protein Eng. Des. Sel. 2014, 27, 255-262. [CrossRef]

8. Morais, S.; Stern, J.; Kahn, A.; Galanopoulou, A.P.; Yoav, S.; Shamshoum, M.; Smith, M.A.; Hatzinikolaou, D.G.; Arnold, F.H.; Bayer, E.A. Enhancement of cellulosome-mediated deconstruction of cellulose by improving enzyme thermostability. Biotechnol. Biofuels 2016, 9, 164. [CrossRef]

9. Ribeiro, A.L.; Sanchez, M.; Hidalgo, A.; Berenguer, J. Stabilization of enzymes by using thermophiles. Methods Mol. Biol. 2017, 1645, 297-312.

10. Merz, A.; Yee, M.C.; Szadkowski, H.; Pappenberger, G.; Crameri, A.; Stemmer, W.P.; Yanofsky, C.; Kirschner, K. Improving the catalytic activity of a thermophilic enzyme at low temperatures. Biochemistry 2000, 39, 880-889. [CrossRef] [PubMed]

11. Lebbink, J.H.; Kaper, T.; Bron, P.; van der Oost, J.; de Vos, W.M. Improving low-temperature catalysis in the hyperthermostable pyrococcus furiosus beta-glucosidase celb by directed evolution. Biochemistry 2000, 39, 3656-3665. [CrossRef]

12. Sunna, A.; Moracci, M.; Rossi, M.; Antranikian, G. Glycosyl hydrolases form hyperthermophiles. Extremophiles 1997, 1, 2-13. [CrossRef]

13. Elleuche, S.; Schroder, C.; Sahm, K.; Antranikian, G. Extremozymes-biocatalysts with unique properties from extremophilic microorganisms. Curr. Opin. Biotechnol. 2014, 29, 116-123. [CrossRef]

14. Blumer-Schuette, S.E.; Brown, S.D.; Sander, K.B.; Bayer, E.A.; Kataeva, I.; Zurawski, J.V.; Conway, J.M.; Adams, M.W.W.; Kelly, R.M. Thermophilic lignocellulose deconstruction. FEMS Microbiol. Rev. 2014, 38, 393-448. [CrossRef] [PubMed]

15. Botha, J.; Mizrachi, E.; Myburg, A.A.; Cowan, D.A. Carbohydrate active enzyme domains from extreme thermophiles: Components of a modular toolbox for lignocellulose degradation. Extremophiles 2018, 22, 1-12. [CrossRef] [PubMed] 
16. Lombard, V.; Golaconda Ramulu, H.; Drula, E.; Coutinho, P.M.; Henrissat, B. The carbohydrate-active enzymes database (cazy) in 2013. Nucleic Acids Res. 2014, 42, D490-D495. [CrossRef] [PubMed]

17. Pisani, F.M.; Rella, R.; Raia, C.A.; Rozzo, C.; Nucci, R.; Gambacorta, A.; De Rosa, M.; Rossi, M. Thermostable beta-galactosidase from the archaebacterium sulfolobus solfataricus. Purification and properties. Eur. J. Biochem. 1990, 187, 321-328. [CrossRef] [PubMed]

18. Moracci, M.; Lavolpe, A.; Pulitzer, J.F.; Rossi, M.; Ciaramella, M. Expression of the thermostable beta-galactosidase gene from the archaebacterium sulfolobus-solfataricus in saccharomyces-cerevisiae and characterization of a new inducible promoter for heterologous expression. J. Bacteriol. 1992, 174, 873-882. [CrossRef] [PubMed]

19. Moracci, M.; Ciaramella, M.; Nucci, R.; Pearl, L.H.; Sanderson, I.; Trincone, A.; Rossi, M. Thermostable $\beta$-glycosidase from sulfolobus-solfataricus. Biocatalysis 1994, 11, 89-103. [CrossRef]

20. Moracci, M.; Nucci, R.; Febbraio, F.; Vaccaro, C.; Vespa, N.; Lacara, F.; Rossi, M. Expression and extensive characterization of a beta-glycosidase from the extreme thermoacidophilic archaeon sulfolobus-solfataricus in escherichia-coli - authenticity of the recombinant enzyme. Enzyme Microb. Tech. 1995, 17, 992-997. [CrossRef]

21. Pouwels, J.; Moracci, M.; Cobucci-Ponzano, B.; Perugino, G.; van der Oost, J.; Kaper, T.; Lebbink, J.H.G.; de Vos, W.M.; Ciaramella, M.; Rossi, M. Activity and stability of hyperthermophilic enzymes: A comparative study on two archaeal beta-glycosidases. Extremophiles 2000, 4, 157-164. [CrossRef]

22. Leon, M.; Isorna, P.; Menendez, M.; Sanz-Aparicio, J.; Polaina, J. Comparative study and mutational analysis of distinctive structural elements of hyperthermophilic enzymes. Protein J. 2007, 26, 435-444. [CrossRef] [PubMed]

23. Aguilar, C.F.; Sanderson, I.; Moracci, M.; Ciaramella, M.; Nucci, R.; Rossi, M.; Pearl, L.H. Crystal structure of the beta-glycosidase from the hyperthermophilic archeon sulfolobus solfataricus: Resilience as a key factor in thermostability. J. Mol. Biol. 1997, 271, 789-802. [CrossRef]

24. Cobucci-Ponzano, B.; Moracci, M.; Di Lauro, B.; Ciaramella, M.; D'Avino, R.; Rossi, M. Ionic network at the c-terminus of the beta-glycosidase from the hyperthermophilic archaeon sulfolobus solfataricus: Functional role in the quaternary structure thermal stabilization. Proteins 2002, 48, 98-106. [CrossRef]

25. Ausili, A.; Di Lauro, B.; Cobucci-Ponzano, B.; Bertoli, E.; Scire, A.; Rossi, M.; Tanfani, F.; Moracci, M. Two-dimensional ir correlation spectroscopy of mutants of the beta-glycosidase from the hyperthermophilic archaeon sultolobus soltataricus identifies the mechanism of quaternary structure stabilization and unravels the sequence of thermal unfolding events. Biochem. J. 2004, 384, 69-78. [CrossRef]

26. Tehei, M.; Franzetti, B.; Madern, D.; Ginzburg, M.; Ginzburg, B.Z.; Giudici-Orticoni, M.T.; Bruschi, M.; Zaccai, G. Adaptation to extreme environments: Macromolecular dynamics in bacteria compared in vivo by neutron scattering. Embo. Rep. 2004, 5, 66-70. [CrossRef] [PubMed]

27. Kalimeri, M.; Rahaman, O.; Melchionna, S.; Sterpone, F. How conformational flexibility stabilizes the hyperthermophilic elongation factor g-domain. J. Phys. Chem. B 2013, 117, 13775-13785. [CrossRef] [PubMed]

28. Matsuura, Y.; Takehira, M.; Joti, Y.; Ogasahara, K.; Tanaka, T.; Ono, N.; Kunishima, N.; Yutani, K. Thermodynamics of protein denaturation at temperatures over 100 degrees c: Cuta1 mutant proteins substituted with hydrophobic and charged residues. Sci. Rep. 2015, 5, 15545. [CrossRef]

29. Deckert, K.; Budiardjo, S.J.; Brunner, L.C.; Lovell, S.; Karanicolas, J. Designing allosteric control into enzymes by chemical rescue of structure. J. Am. Chem. Soc. 2012, 134, 10055-10060. [CrossRef]

30. Budiardjo, S.J.; Licknack, T.J.; Cory, M.B.; Kapros, D.; Roy, A.; Lovell, S.; Douglas, J.; Karanicolas, J. Full and partial agonism of a designed enzyme switch. ACS Synth. Biol. 2016, 5, 1475-1484. [CrossRef]

31. Nucci, R.; Moracci, M.; Vaccaro, C.; Vespa, N.; Rossi, M. Exo-glucosidase activity and substrate-specificity of the beta-glycosidase isolated from the extreme thermophile sulfolobus-solfataricus. Biotechnol. Appl. Bioc. 1993, 17, 239-250.

32. Corbett, K.; Fordham-Skelton, A.P.; Gatehouse, J.A.; Davis, B.G. Tailoring the substrate specificity of the beta-glycosidase from the thermophilic archaeon sulfolobus solfataricus. Febs. Lett. 2001, 509, 355-360. [CrossRef]

33. Hancock, S.M.; Corbett, K.; Fordham-Skelton, A.P.; Gatehouse, J.A.; Davis, B.G. Developing promiscuous glycosidases for glycoside synthesis: Residues w433 and e432 in sulfolobus solfataricus beta-glycosidase are important glucoside- and galactoside-specificity determinants. Chembiochem 2005, 6, 866-875. [CrossRef] [PubMed] 
34. Iglesias-Fernandez, J.; Hancock, S.M.; Lee, S.S.; Khan, M.; Kirkpatrick, J.; Oldham, N.J.; McAuley, K.; Fordham-Skelton, A.; Rovira, C.; Davis, B.G. A front-face 'sni synthase' engineered from a retaining 'double-sn2' hydrolase. Nat. Chem. Biol. 2017, 13, 874-881. [CrossRef]

35. Mackenzie, L.F.; Wang, Q.P.; Warren, R.A.J.; Withers, S.G. Glycosynthases: Mutant glycosidases for oligosaccharide synthesis. J. Am. Chem. Soc. 1998, 120, 5583-5584. [CrossRef]

36. Moracci, M.; Trincone, A.; Perugino, G.; Ciaramella, M.; Rossi, M. Restoration of the activity of active-site mutants of the hyperthermophilic beta-glycosidase from sulfolobus solfataricus: Dependence of the mechanism on the action of external nucleophiles. Biochemistry 1998, 37, 17262-17270. [CrossRef] [PubMed]

37. Trincone, A.; Perugino, G.; Rossi, M.; Moracci, M. A novel thermophilic glycosynthase that effects branching glycosylation. Bioorg. Med. Chem. Lett. 2000, 10,365-368. [CrossRef]

38. Moracci, M.; Trincone, A.; Rossi, M. Glycosynthases: New enzymes for oligosaccharide synthesis. J. Mol. Catal. B-Enzym 2001, 11, 155-163. [CrossRef]

39. Cobucci-Ponzano, B.; Strazzulli, A.; Rossi, M.; Moracci, M. Glycosynthases in biocatalysis. Adv. Synth. Catal. 2011, 353, 2284-2300. [CrossRef]

40. Cobucci-Ponzano, B.; Moracci, M. Glycosynthases as tools for the production of glycan analogs of natural products. Nat. Prod. Rep. 2012, 29, 697-709. [CrossRef] [PubMed]

41. Wei, J.H.; Lv, X.; Lu, Y.; Yang, G.Z.; Fu, L.F.; Yang, L.; Wang, J.J.; Gao, J.H.; Cheng, S.H.; Duan, Q.; et al. Glycosynthase with broad substrate specificity-an efficient biocatalyst for the construction of oligosaccharide library. Eur. J. Org. Chem. 2013, 2414-2419. [CrossRef]

42. Planas, A. Glycosynthase technology for enzymatic synthesis of functional polysaccharides. Abstr. Pap. Am. Chem. Soc. 2015, 249.

43. Goddard-Borger, E.D.; Tysoe, C.; Withers, S.G. Glycosynthase mediated synthesis of psychosine. Carbohydr. Res. 2016, 435, 97-99. [CrossRef]

44. Gloster, T.M.; Roberts, S.; Ducros, V.M.A.; Perugino, G.; Rossi, M.; Hoos, R.; Moracci, M.; Vasella, A.; Davies, G.J. Structural studies of the beta-glycosidase from sulfolobus solfataricus in complex with covalently and noncovalently bound inhibitors. Biochemistry 2004, 43, 6101-6109. [CrossRef]

45. Gloster, T.M.; Roberts, S.; Perugino, G.; Rossi, M.; Moracci, M.; Panday, N.; Terinek, M.; Vasella, A.; Davies, G.J. Structural, kinetic, and thermodynamic analysis of glucoimidazole-derived glycosidase inhibitors. Biochemistry 2006, 45, 11879-11884. [CrossRef]

46. Hill, C.M.; Duggleby, R.G. Mutagenesis of escherichia coli acetohydroxyacid synthase isoenzyme ii and characterization of three herbicide-insensitive forms. Biochem. J. 1998, 335, 653-661. [CrossRef]

47. Shimotohno, A.; Oue, S.; Yano, T.; Kuramitsu, S.; Kagamiyama, R. Demonstration of the importance and usefulness of manipulating non-active-site residues in protein design. J. Biochem. 2001, 129, 943-948. [CrossRef] [PubMed]

48. Agarwal, P.K. A biophysical perspective on enzyme catalysis. Biochemistry 2019, 58, 438-449. [CrossRef]

49. Romero, P.A.; Arnold, F.H. Exploring protein fitness landscapes by directed evolution. Nat. Rev. Mol. Cell Biol. 2009, 10, 866-876. [CrossRef]

50. Giver, L.; Gershenson, A.; Freskgard, P.O.; Arnold, F.H. Directed evolution of a thermostable esterase. Proc. Natl. Acad. Sci. USA 1998, 95, 12809-12813. [CrossRef]

51. Kyte, J.; Doolittle, R.F. A simple method for displaying the hydropathic character of a protein. J. Mol. Biol. 1982, 157, 105-132. [CrossRef]

52. Zhou, W.; Huang, R.; Zhu, Z.; Zhang, Y.P.J. Coevolution of both thermostability and activity of polyphosphate glucokinase from thermobifida fusca yx. Appl. Environ. Microbiol. 2018, 84, e01224-18. [CrossRef]

53. Arnold, F.H.; Wintrode, P.L.; Miyazaki, K.; Gershenson, A. How enzymes adapt: Lessons from directed evolution. Trends Biochem. Sci 2001, 26, 100-106. [CrossRef]

54. Moracci, M.; Capalbo, L.; Ciaramella, M.; Rossi, M. Identification of two glutamic acid residues essential for catalysis in the beta-glycosidase from the thermoacidophilic archaeon sulfolobus solfataricus. Protein Eng. 1996, 9, 1191-1195. [CrossRef]

55. Griffith, K.L.; Wolf, R.E., Jr. Measuring beta-galactosidase activity in bacteria: Cell growth, permeabilization, and enzyme assays in 96-well arrays. Biochem. Biophys. Res. Commun. 2002, 290, 397-402. [CrossRef] [PubMed] 
56. Perugino, G.; Trincone, A.; Giordano, A.; van der Oost, J.; Kaper, T.; Rossi, M.; Moracci, M. Activity of hyperthermophilic glycosynthases is significantly enhanced at acidic ph. Biochemistry 2003, 42, 8484-8493. [CrossRef] [PubMed]

57. Bradford, M.M. A rapid and sensitive method for the quantitation of microgram quantities of protein utilizing the principle of protein-dye binding. Anal. Biochem. 1976, 72, 248-254. [CrossRef]

58. Arnold, K.; Bordoli, L.; Kopp, J.; Schwede, T. The swiss-model workspace: A web-based environment for protein structure homology modelling. Bioinformatics 2006, 22, 195-201. [CrossRef] [PubMed]

59. Laskowski, R.A.; Macarthur, M.W.; Moss, D.S.; Thornton, J.M. Procheck: a program to check the stereochemical quality of protein structures. J. Appl. Crystallogr. 1993, 26, 283-291. [CrossRef]

(C) 2019 by the authors. Licensee MDPI, Basel, Switzerland. This article is an open access article distributed under the terms and conditions of the Creative Commons Attribution (CC BY) license (http://creativecommons.org/licenses/by/4.0/). 